\title{
Adenine Uptake Cells in the Rat Kidney with Remarks on the Expression of Ia Antigen
}

\author{
Bunsuke Osogok ${ }^{1}$, Tetsuo Fukumoto ${ }^{2}$ and Satimaru SENo ${ }^{1}$ \\ Division of Pathology ${ }^{1}$, Shigei Medical Research Institute, Okayama; and Department of Anatomy ${ }^{2}$, Yamaguchi University \\ School of Medicine, Ube, Japan \\ Received January 27, 1989
}

Summary. The patterns of $\left[{ }^{14} \mathrm{C}\right]$ adenine $\left(\left[{ }^{14} \mathrm{C}\right] \mathrm{A}\right)$ incorporation into DNA by proliferative cells in the kidney were studied by the autoradiographic technique. It was revealed that, after 3 daily injections of $\left[{ }^{14} \mathrm{C}\right] \mathrm{A}$ (1 $\mu \mathrm{Ci} / \mathrm{g}$ body weight each), a portion of the glon.erular cells and a few fibroblastoid cells in the cortical intexstitium incorporated $\left[{ }^{14} \mathrm{C}\right] \mathrm{A}$ into DNA to a remarkable extent. Such cells also incorporated $\left[{ }^{3} \mathrm{H}\right]$ thymidine, but to a lesser extent.

The cells which incorporate $\left[{ }^{14} \mathrm{C}\right] \mathrm{A}$ to a particularly great extent (adenine uptake cells) also occur in other tissues. Such cells are confined to a few cell types of either the macrophage or fibroblast or reticulum cell lines. This fact suggests that the adenine uptake cells observed in the glomerulus are also of a similar cell line and most likely mesangial cells.

By immunohistochemical examination for Ia antigen, adenine uptake cells are divided into Ia-positive and Ia-negative types. The present examination showed that the major portion of adenine uptake cells in the glomerulus are Ia-negative, and it is suggested that these cells are analogous to the Ia-negative macrophages in the lung. This suggestion is supported by the fact that, in the glomerulus, colloidal carbon uptake cells (macrophage-like cells) are present in fairly large numbers. The Ia-positive cells seem to be of the same cell line as the adenine uptake cells that express Ia antigen in other tissues, such as septal fibroblasts in the lung.

$\left[{ }^{3} \mathrm{H}\right]$ thymidine $\left(\left[{ }^{3} \mathrm{H}\right] \mathrm{TdR}\right)$ is incorporated into proliferative cells parallel with the progress of DNA synthesis, and it is generally believed that there are no great variations in the labeling intensity among different cell types. However, OSOGOE and YANAGI $(1982,1987 \mathrm{a})$ have revealed that the incorporation of $\left[{ }^{14} \mathrm{C}\right]$ adenine $\left(\left[{ }^{14} \mathrm{C}\right] \mathrm{A}\right)$ into nucleic acid, DNA in particular, by blood monocytes and their precursor cells in the bone marrow of rats, takes place to a much greater extent than that of other types of blood cells.
The cells which incorporate $\left[{ }^{14} \mathrm{C}\right] \mathrm{A}$ to a particularly great extent (adenine uptake cells) also occur in various tissues and organs. Such cells are confined to a few cell types which are of either the macrophage or fibroblast or reticulum cell lines (OSOGOE and YANAGI, 1987b-d; OSOGOE and UMEBAYASHI-YANAGI, 1989). In a search for another cell marker that may be substituted for $\left[{ }^{14} \mathrm{C}\right]$ A labeling, we incidentally found that a portion of adenine uptake cells express Ia antigen, i.e., one of the immunological markers of the cells that participate in the immune response (OSOGOE and FUKUMOTO, unpublisged observation).

In this work, the incorporation patterns of $\left[{ }^{14} \mathrm{C}\right] \mathrm{A}$ and, as control, $\left[{ }^{3} \mathrm{H}\right] \mathrm{TdR}$ by proliferative cells in the rat kidney were studied by the autoradiographic technique, along with an immunohistochemical examination to detect Ia antigen on these cells.

This paper also includes a brief mention and illustrations of findings in the lung because the pattern of cellular reactivity in the lung was comparable with that in the kidney, glomerulus in particular.

\section{MATERIALS AND METHODS}

Male Wistar rats weighing around $80 \mathrm{~g}$ were reared on a compressed diet (Oriental MF, Japan) for a week or two, and animals which grew at normal rates were considered healthy and used in this study. Two series of experiment were conducted as follows:

\section{Autoradiographic labeling}

Six rats weighing around $150 \mathrm{~g}$ received 3 daily subcutaneous injections of $\left[8^{-14} \mathrm{C}\right]$ adenine (specific activity, $40-60 \mathrm{mCi} / \mathrm{mM}$ ) in a dose of $1 \mu \mathrm{Ci}$ per $\mathrm{g}$ of body weight each and at $24 \mathrm{~h}$ interval. As control, 4 rats were injected with [ methyl ${ }^{3} \mathrm{H}$ ] thymidine (specific activity, $20 \mathrm{Ci} / \mathrm{mM}$ ) with the same dose and 
in the same manner as $\left[{ }^{14} \mathrm{C}\right] \mathrm{A}$. The radiochemicals were purchased from New England Nuclear Corp., Boston, U.S.A.

As $3 \mathrm{~h}$ after the last injection, the rats were sacrificed and the kidney and other tissues were excised for examination. The tissues were fixed in Carnoy's fluid, embedded in paraffin and cut serially into $4 \mu \mathrm{m}$ thick sections.

Autoradiographs were made by dipping the sections into Sakura NR-M2 liquid emulsion. Before preparation of autoradiographs, the sections were washed in running water for $1 \mathrm{~h}$ to remove soluble radioactivity. The exposure time was limited to 2 weeks. After photographic processing, the sections were stained with hematoxylin and eosin.

Since adenine is incorporated ioto both DNA and RNA, RNA was extracted from the sections by RNase A treatment before preparation of autoradiographs with $\left[{ }^{14} \mathrm{C}\right] \mathrm{A}$. The incorporation of $\left[{ }^{14} \mathrm{C}\right] \mathrm{A}$ into

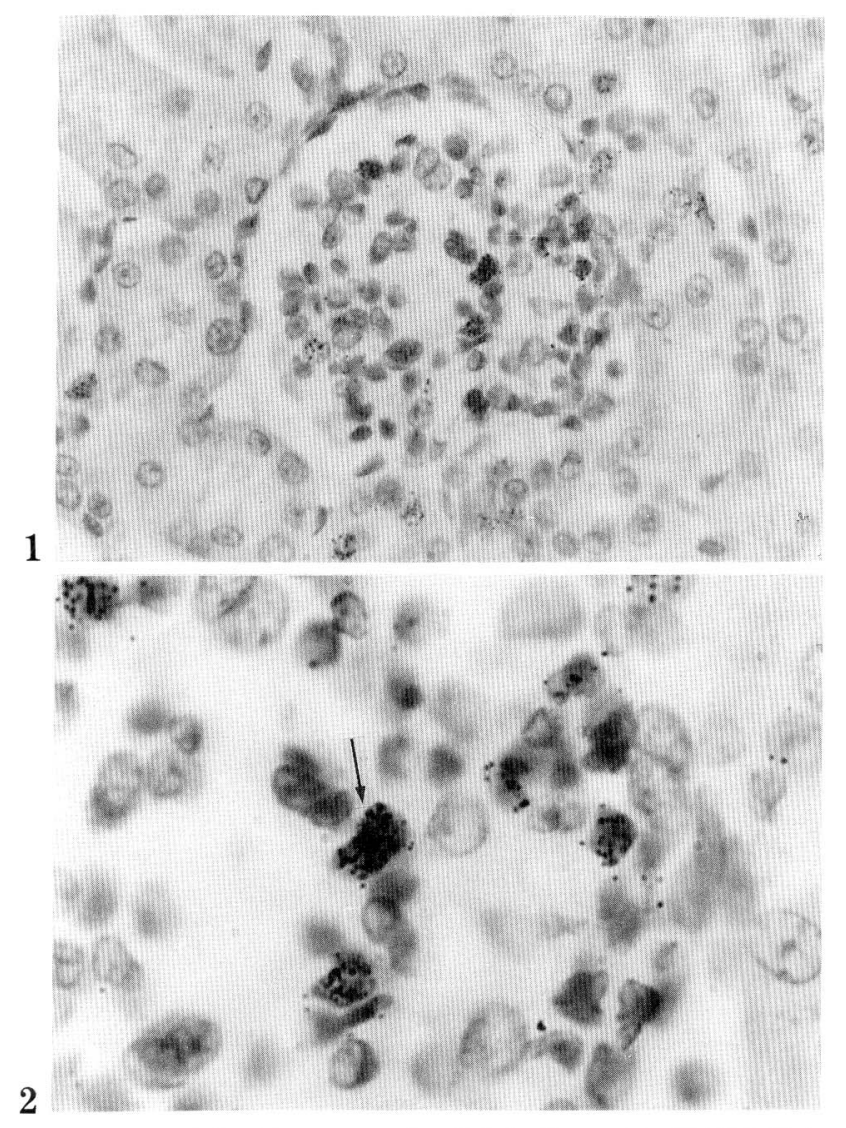

Figs. 1 and 2. Patterns of cell labeling with $\left[{ }^{3} \mathrm{H}\right] \mathrm{TdR}$ in a section of the kidney. Exposure time: 2 weeks. Fig. 1. Cell labeling within a glomerulus. $\times 320$. Fig. 2. Higher magnification of the same glomerular cells as shown Figure 1. Notice a large cell showing especially strong labeling (arrow) in the perivascular area. $\times 1,000$
DNA by the cells was confirmed by pretreatment of the sections with DNase I. RNase and DNase were obtained from Worthington Biochemical Co., Freehold, U. S. A.

\section{Immunohistochemical staining}

Immunohistochemical staining of the cells and tissues to be examined was conducted according to the methods described by FujIKURA et al. (1985). The 10 $\mu \mathrm{m}$ frozen section of tissues was incubated with 100 $\mu l$ of monoclonal antibody OX-6 (Serotec, Ltd., Bicester, Oxford Shire, U.K.) for $1 \mathrm{~h}$ at room temperature, washed three times in cold phosphate-buffered saline (PBS) and then incubated at $4^{\circ} \mathrm{C}$ for $1 \mathrm{~h}$ with $100 \mu \mathrm{l}$ of horseradish peroxidase conjugated rabbit $\mathrm{F}(\mathrm{ab})_{2}$ anti-mouse IgG (Cappel Laboratories, Inc., U.S.A.). After washing with PBS, the sections were incubated for 5 min with 3, 3'-diaminobenzidine $\mathrm{HCl}$.

\section{RESULTS}

\section{Autoradiographic labeling with $\left[{ }^{3} \mathrm{H}\right] \mathrm{TdR}$}

In the rats that received 3 daily injections of $\left[{ }^{3} \mathrm{H}\right]$ $\mathrm{TdR}$, cell lbabeling was apparent on a portion of the glomerular cells. Not infrequently, several cells within a single glomerulus were labeled (Figs. 1, 2). The other cell types outside of the glomeruli which showed occasional labeling with $\left[{ }^{3} \mathrm{H}\right] \mathrm{TdR}$ included epithelial cells (their nuclei) of the proximal convoluted tubules and a few fibroblastoid cells (also their nuclei) in the cortical interstitium.

\section{Autoradiographic labeling with $\left[{ }^{14} \mathrm{C}\right] \mathrm{A}$}

After 3 daily injections of $\left[{ }^{14} \mathrm{C}\right] \mathrm{A}$, the general patterns of cellular labeling in the kidney were the same as those observed after injections of $\left[{ }^{3} \mathrm{H}\right] \mathrm{TdR}$. In the case of $\left[{ }^{14} \mathrm{C}\right] \mathrm{A}$ labeling, however, a greater number of glomerular cells were labeled and, moreover, the intensity of cellular labeling was much stronger than in the case of $\left[{ }^{3} \mathrm{H}\right] \mathrm{TdR}$ labeling (Figs. 3 , 4). Among the labeled glomerular cells, a marked tendency was observed for cells having large nuclei exhibiting stronger labeling than cells with smaller nuclei.

In addition to glomerular cells, a few fibroblastoid cells in the interstitium between renal tubules of the cortex also exhibited heavy labeling with $\left[{ }^{14} \mathrm{C}\right] \mathrm{A}$ even after RNase treatment (Fig. 5). The epithelial cells of tubules (their nuclei) remained almost unlabeled following RNase treatment.

The cell labeling with $\left[{ }^{14} \mathrm{C}\right] \mathrm{A}$ following RNase treatment vanished completely with the extraction of 
DNA from the cells with DNase treatment. This indicates that the cell labeling observed following RNase treatments represents the incorporation of $\left[{ }^{14} \mathrm{C}\right] \mathrm{A}$ into DNA (i.e., DNA labeling).

\section{Immunohistochemical staining for Ia antigen}

The occurrence of Ia-positive cells in the kidney, particularly in the glomerulus, has been reported by several investigators (HALLORAN et al., 1980; SCHREINER et al., 1981; SCHREINER and COTRAN, 1982; GURNER et al., 1987). The present study confirmed the earlier observations; a few Ia-positive cells was observed not only in the glomerulus but also in the cortical interstitium (Figs. 6, 7). When compared with the number of adenine uptake cells in the glomerulus, however, the number of Ia-positive cells in this area was definitely smaller. This indicates that the major portion of adenine uptake cells in the glomerulus are Ia-negative.

The Ia-positive cells were similar in morphology and topographical distribution to the adenine uptake cells, especially those with large nuclei and exhibiting particularly strong labeling with $\left[{ }^{14} \mathrm{C}\right] \mathrm{A}$.

The above-mentioned findings in the kidney are comparable with those in the lung. As has been reported by OSOGOE and YANAGI (1987b), both alveolar macrophages and septal cells (fibroblasts) in the interalveolar septum exhibit remarkable labeling with $\left[{ }^{14} \mathrm{C}\right] \mathrm{A}$ even after RNase treatment (Figs. 8, 9). By immunohistochemical examination, however, only septal fibroblasts were found to express Ia antigen, whereas the other cells including alveolar macrophages were Ia-negative (Fig. 10).

\section{DISCUSSION}

The present study has demonstrated a high rate of $\left[{ }^{14} \mathrm{C}\right] \mathrm{A}$ uptake by a portion of glomerular cells and a few fibroblastoid cells in the cortical interstitium. By treatment with RNase or DNase or both, it was confirmed that the incorporation of $\left[{ }^{14} \mathrm{C}\right] \mathrm{A}$ by these cells takes place for the most part into DNA. This is supported by the fact that the cells labeled with $\left[{ }^{14} \mathrm{C}\right] \mathrm{A}$ also exhibited $\left[{ }^{3} \mathrm{H}\right] \mathrm{TdR}$ labeling, although the cellular labeling with $\left[{ }^{3} \mathrm{H}\right] \mathrm{TdR}$ was much weaker in intensity than that with $\left[{ }^{14} \mathrm{C}\right] \mathrm{A}$.

With respect to the identification of labeled glomerular cells, two possibilities must be considered, as PABST and STERZEL (1983) have reported that among glomerular cells either mesangial cells or endothelial cells, especially the latter, become labeled with $\left[{ }^{3} \mathrm{H}\right]$
TdR. In the present experiments, none of the labeled glomerular cells were identified with certainty as endothelial cells. As mentioned in the introduction,

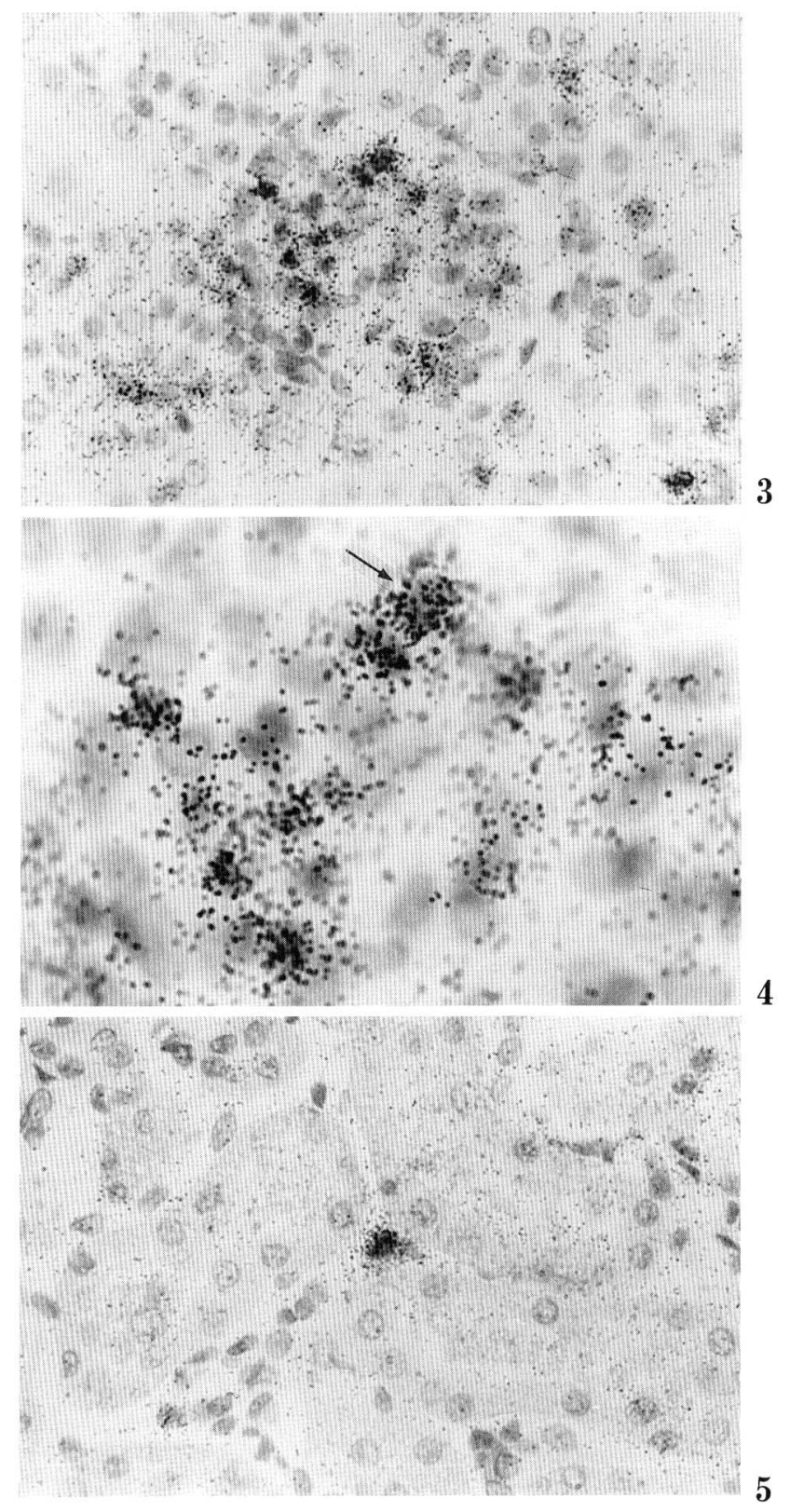

Figs. 3-5. The patterns of cell labeling with $\left[{ }^{14} \mathrm{C}\right] \mathrm{A}$ in the section of the kidney after RNase treatment. Exposure time: 2 weeks. Fig. 3. Cell labeling within a glomerulus. Several cells show fairly strong labeling. $\times 320$. Fig. 4. Higher magnification of the same glomerular cells as shown in Figure 3. Notice the most heavily labeled cell with a large round nucleus (arrow). $\times 1,000$. Fig. 5. A large, heavily labeled fibroblastoid cell in the interstitium of the cortex (in the center of the figure). $\times 340$ 
adenine uptake cells also occur, though in limited numbers, in various organs and tissues other than the kidney. Such cells are confined to a few cell types such as monocytic cells and other macrophages, proliferative reticulum cells and some fibroblastoid cells (OSOGOE and YANAGI, 1987a-d; OSOGOE and UMEBAYASHI-YANAGI, 1989). Neither epithelial cells or endotholial cells, even rapidly dividing epithelial
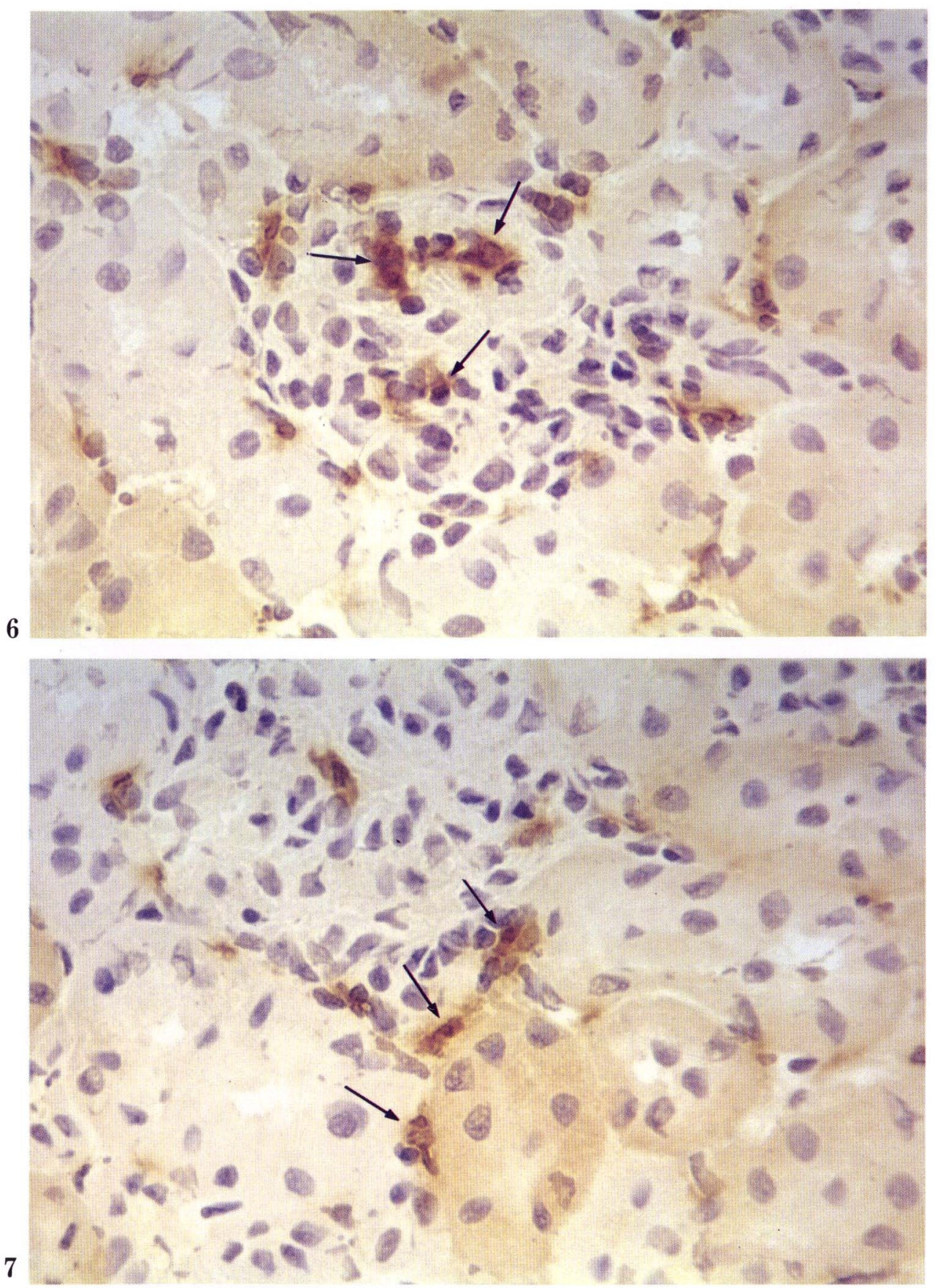

Figs. 6 and 7. Immunohistochemical staining for Ia antigen of glomerular and fibroblastoid cells of the kidney. $\times 400$. Fig. 6. Ia-positive glomerular cells (arrows) within a glomerulus. Fig. 7. Ia-positive fibroblastoid cells (arrows) that occur in the interstitium of the cortex. Notice that the epithelial cells of the proximal convoluted tubules are weakly Ia-positive. 


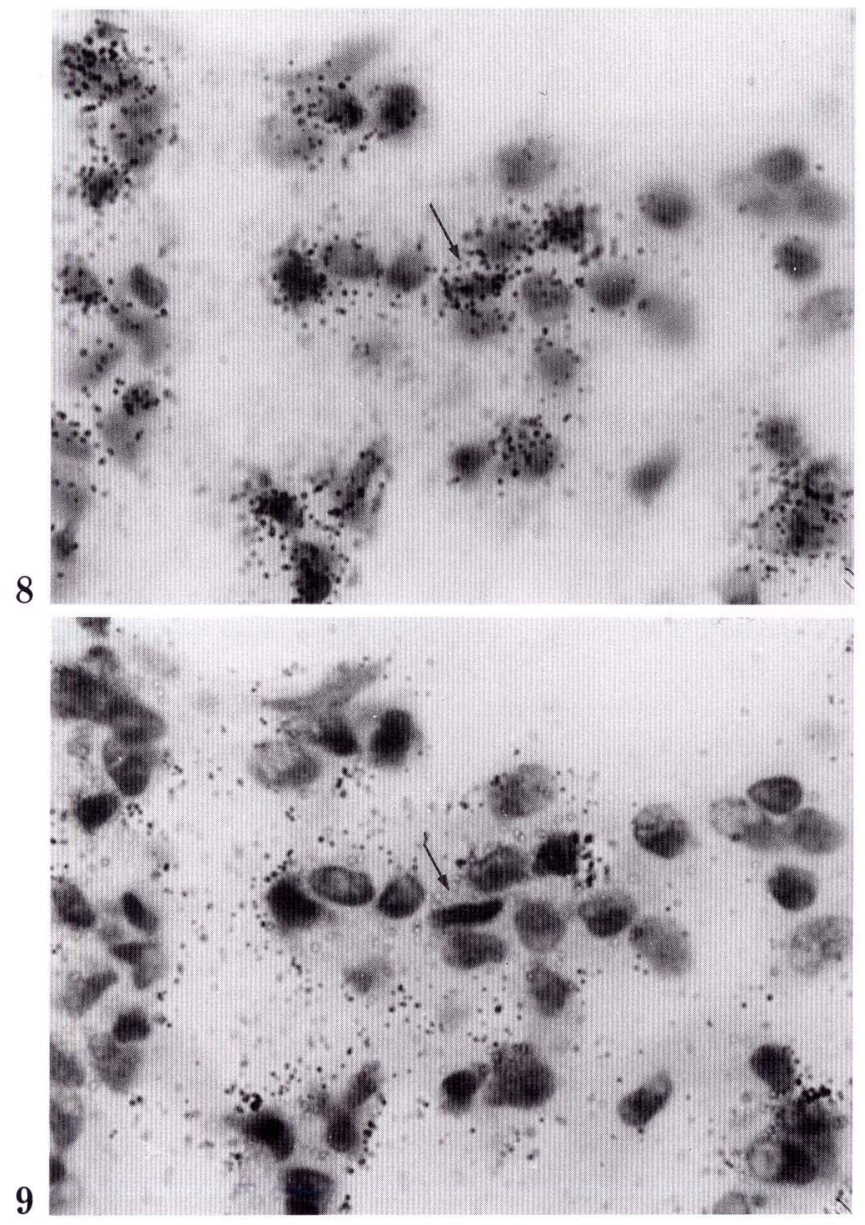

cells of small intestinal mucosa, ever incorporate $\left[{ }^{14} \mathrm{C}\right] \mathrm{A}$ to a remarkable extent. These findings suggest that the glomerular cells labeled with $\left[{ }^{14} \mathrm{C}\right] \mathrm{A}$ are not endothelial cells but most likely mesangial cells.

A few fibroblastoid cells that revealed strong labeling with $\left[{ }^{14} \mathrm{C}\right] \mathrm{A}$ in the cortical interstitium are comparable with similar cells in the connective tissues of other organs, such as septal fibroblasts in the interalveolar septum of the lung, but the nature and function of such cells is not clear.

The mechanism by which $\left[{ }^{14} \mathrm{C}\right] \mathrm{A}$ is incorporated by a few cell types to a particularly great extent is not clear. However, it is conceivable that adenine metabolism of such cell types differs from that of the other cell types. According to HENDERSON and PATTERSON (1973), some animal cells have an absolute requirement for exogenously supplied purine because of a deficiency in the enzyme system in the pathway of synthesis de novo; the large majority of the other cell types are capable of synthesizing via the de novo pathway to a greater or lesser extent.

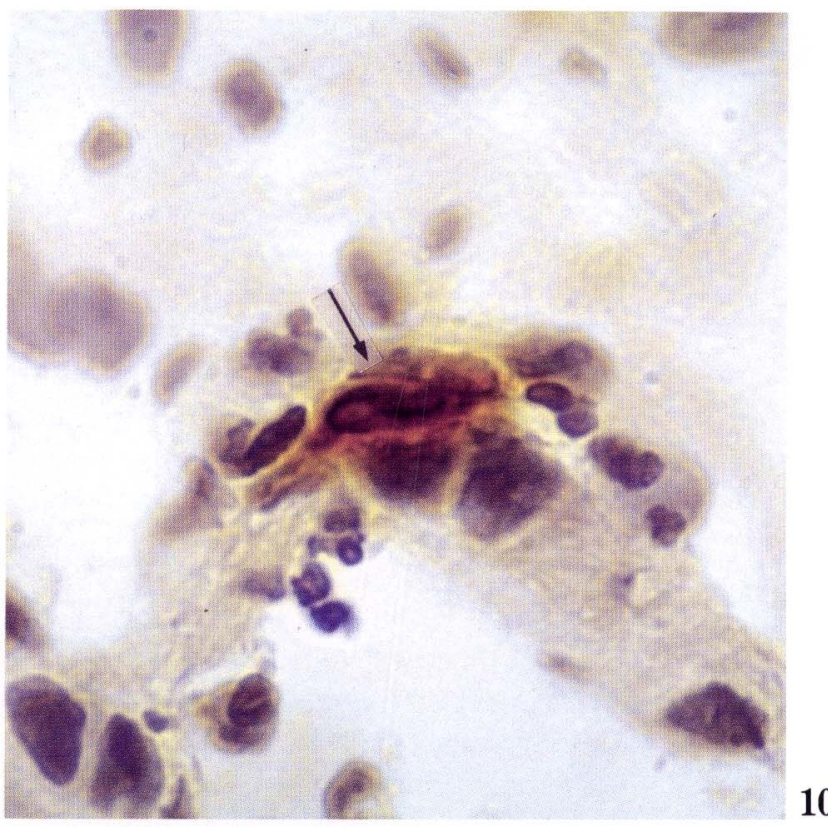

Figs. 8 and 9. Patterns of cell labeling with $\left[{ }^{14} \mathrm{C}\right] \mathrm{A}$ of the alveolar wall in a section of the lung after RNase treatment. Exposure time: 2 weeks. $\times 800$. Fig. 8 . Strong labeling of numerous alveolar macrophages and one septal fibroblast (arrow). Fig. 9. The same picture as shown in Figure 8 but focused on the nucleus of one septal fibroblast (arrow).

Fig. 10. One septal fibroblast stained positive for Iaantigen (arrow). Notice that the other cells including alveolar macrophages are Ia-negative. $\times 1,300$

The adenine uptake cells in the kidney and other tissues seem to be one of the former cell types which have a strong requirement for exogenously supplied adenine. From the biochemical viewpoint, therefore, the term adenine-requiring cell is preferable to adenine uptake cell.

In a search for another cell marker that may be sustituted for $\left[{ }^{14} \mathrm{C}\right] \mathrm{A}$ labeling, OSOGOE and FUKUMOTO incidentally found that a portion of adenine uptake cells show positive reaction for Ia antigen (unpublished observation). This antigen was originally considered an immunological marker of B-lymphocytes, but later other cells, such as dendritic cells (cells resembling reticulum cells), were also found to express this antigen (ToKUnAGA et al., 1981; TEw et al., 1982). Among adenine uptake cells, alveolar macrophages in the lung showed negative reaction for Ia, whereas reticulum cell and fibroblastoid cells were Ia-positive. The present immunohistochemical study revealed that the major portion of adenine uptake cells in the glomerulus are Ia-negative, where- 
as a limited portion of glomerular cells and few fibroblastoid cells in the cortical interstitum are Iapositive.

These findings suggest that the Ia-negative portion of adenine uptake cells in the glomerulus are analogous to the Ia-negative macrophages in the lung. This suggestion is supported by the fact that, in the glomerulus, colloidal carbon uptake cells (macrophagelike cells) are present in fairly large numbers, as has been reported by ElEMA et al. (1976) and HOYER et al. (1976). OSOGOE and HAYASHI reconfirmed this fact in another experiment (unpublished observation).

With regard to the relation of Ia-positive cells to the adenine uptake cells, the authors with to emphasize the finding that the former cells are similar in morphology and topographical distribution to the latter cells, especially those that have large nuclei and exhibit particularly strong labeling with $\left[{ }^{14} \mathrm{C}\right] \mathrm{A}$. The Ia-positive cells in the kidney seem to be of the same cell line as the adenine uptake cells that express Ia antigen in other tissues, such as septal fibroblasts in the lung (described in this paper) or proliferative reticulum cells in the small intestinal mucosa (to be published in another paper).

Acknowledgements. We are indebted to Miss M. YANAGI, Department of Anatomy, Kawasaki Medical School for preparing autoradiographs and to Mr. M. TAMECHIKA and Mr. A. KUMAKURA, Department of Anatomy, Yamaguchi University School of Medicine, for performing immunohistochemical staining. We also thank Miss N. NisHIмото, Shigei Medical Research Institute, for secretarial assistance.

\section{REFERENCES}

Elema, J. D., J. R. Hoyer and R. L. Vernier: The glomerular mesangium: Uptake and transport of intravascularly injected colloidal carbon in rats. Kidney Int. 9: 395-406 (1976).

Fujikura, Y., H. KUniki and T. Fukumoto: Monoclonal antibodies against fetal rat liver cells. Bull. Yamaguchi Med. Sch. 32: 21-26 (1985).

Gurner, A. C., J. Smith and V. CATtell: The origin of Ia antigen-expressing cells in the rat kidney. Amer. J. Pathol. 127: 342-348 (1987).

Halloran, P., D. Duton, S. Stylianos and M. Stubbs: Expression of Ia in mouse kidney. Transplantation (Baltimore) 30: 256-263 (1980).

Henderson, J. F. and A. R. P. Patterson: Nucleotide metabolism: An introduction. Academic Press, New York and London. 1973 (p. 97-123).

Hoyer, J. R., J. D. ElemA and R. L. Vernier: Unilateral renal disease in the rat. II. Glomerular mesangial uptake of colloidal carbon in unilateral aminonucleotide nephrosis and nephrotic serum nephritis. Lab. Invest. 34: 250-255 (1976).

Osogoe, B. and M. YANAGI: Autoradiographic study on the incorporation of carbon-14 labeled formate and adenine into nucleic acid in blood-forming cells. Okajimas Folia Anat. Jap. 58: 567-582 (1982).

- The use of $\left[{ }^{14} \mathrm{C}\right]$ adenine for autoradiographic labeling of blood monocytes and their precursor cells in the bone marrow of rats. Acta Histochem. Cytochem. 20: 1-8 (1987a).

- : Labeling patterns of alveolar macrophages and Kupffer cells with $\left[{ }^{14} \mathrm{C}\right]$ adenine and $\left[{ }^{3} \mathrm{H}\right]$ thymidine in rats and mice. Okajimas Folia Anat. Jap. 64: 121-130 (1987b).

- : Adenine uptake by lamina propria cells in the intestinal mucosa of rats and mice, with special reference to reticulum cells. Acta Histochem. Cytochem. 20: 387-397 (1987c).

-: Adenine uptake by reticulum cells in the lymphoid tissues of rats. Acta Histochem. Cytochem. 20: 399-408 (1987d).

Osogoe, B. and M. Umebayashi-Yanagi: Adenine uptake by connective tissue cells with special reference to macrophage precursors. Okajimas Folia Anat. Jap. 66: 369-379 (1989).

Pabst, R. and R. B. Sterzel: Cell renewal of glomerular cell types in normal rats. An autoradiographic analysis. Kidney Int. 24: 626-631 (1983).

Schreiner, G. F. and R. S. Cotran : Localization of an Ia-bearing glomerular cell in the mesangium. J. Cell Biol. 94: 483-488 (1982).

Schreiner, G. F., J. M. Kiely, R. S. Cotran and E. R. UNANUE: Characterization of resident glomerular cells in the rat expressing Ia determinants and manifesting generally restricted interactions with lymphocytes. J. Clin. Invest. 68: 920-931 (1981).

Tew, J. G., J. G. Thorbecke and R. M. Steinman: Dendritic cells in the immune response: Characteristics and recommended nomenclature (A report from the Reticuloendothelial Society Committe on Nomenclature). J. Reticuloendothel. Soc. 31: 371-380 (1982).

Tokunaga, T., K. S. Akagawa and H. Tanaka: On the role of Ia-positive A cells in immune responses (In Japanese). Metab. Disease 18: 1463-1476 (1981).

Dr. Bunsuke OsogoE Division of Pathology

Shigei Medical Research Institute Yamada 2117, Okayama

701-02 Japan

尾篔越 文亮

701-02 岡山市山田 2117

重井医学研究所

病理部門 